\title{
The Essential Role of Diaminopimelate Dehydrogenase in the Biosynthesis of Lysine by Bacillus sphaericus
}

\author{
By P. J. WHITE \\ Department of Microbiology, The University, Western Bank, Sheffeld S10 2TN, U.K.
}

(Received 9 August 1982)

\begin{abstract}
Extracts of Bacillus sphaericus NCTC 9602 catalysed the formation of meso-diaminopimelate from aspartic $\beta$-semialdehyde plus pyruvate, or from dihydrodipicolinate, even though no activities of tetrahydrodipicolinate acetylase (or succinylase) nor $N$-acetyl-(or $N$-succinyl-)LLdiaminopimelate deacylase nor diaminopimelate epimerase were found. However, mesodiaminopimelate D-dehydrogenase was present, and had very high activity at $\mathrm{pH} 7.5$ in the direction of synthesis of meso-diaminopimelate from tetrahydrodipicolinate. A lysine-requiring mutant of B. sphaericus lacked diaminopimelate dehydrogenase, and this enzyme reappeared in a revertant that grew without lysine. Other lysine-requiring auxotrophs were defective in dihydrodipicolinate synthase or dihydrodipicolinate reductase or diaminopimelate decarboxylase, but had diaminopimelate dehydrogenase. Diaminopimelate dehydrogenase is not important in the assimilation of ammonia. Mutants that lack this enzyme or else cannot make one of its substrates (tetrahydrodipicolinate) still grow rapidly in minimal medium (plus $0.7 \mathrm{~mm}$ L-lysine) containing ammonium chloride $(36 \mathrm{~mm}$ ) as the only major source of nitrogen. The wildtype grew with L-glutamine, but not with glutamate or lysine as sole source of nitrogen.
\end{abstract}

\section{INTRODUCTION}

Bacteria that can make lysine do so by the 'diaminopimelate pathway', which is named after a characteristic intermediate, 2,6-diaminopimelic acid. This metabolic route was first elucidated in Escherichia coli (reviewed by Meister, 1965) in which succinylated intermediates are used at certain steps (Fig. 1). Later, Sundharadas \& Gilvarg (1967) and Weinberger \& Gilvarg (1970) showed that acetylated intermediates were employed in all the species (six) of the genus Bacillus that they examined; succinylated compounds were not metabolized.

In this paper another variation of the diaminopimelate pathway is reported. In Bacillus sphaericus, $\Delta^{1}$-tetrahydrodipicolinate is converted by a single enzymic step to mesodiaminopimelate (Fig. 1) while acylated intermediates and LL-diaminopimelate are not used at all. The enzyme which catalyses this step (meso-diaminopimelate D-dehydrogenase) has been extensively studied (Misono \& Soda, 1980). Misono et al. (1979) proposed the new pathway and suggested that it might play a secondary role in lysine formation by $B$. sphaericus, but these possibilities were not tested experimentally.

Bacillus sphaericus was one of the first bacteria to be assayed for diaminopimelate decarboxylase and diaminopimelate epimerase (Powell \& Strange, 1957). The latter enzyme was not detected, though its absence did not seem remarkable because the function of the enzyme in lysine synthesis by other bacteria (Fig. 1) was not clear at the time, and the ability of $B$. sphaericus to make lysine had not been shown.

The activity of diaminopimelate epimerase in $B$. sphaericus was re-examined when this organism was found to grow with acetate as sole source of carbon (White \& Lotay, 1980). The enzyme was absent, even though diaminopimelate decarboxylase was present with relatively high activity. The lack of the epimerase means that neither of the established variants of the diaminopimelate pathway can operate in B. sphaericus, because diaminopimelate decarboxylase 


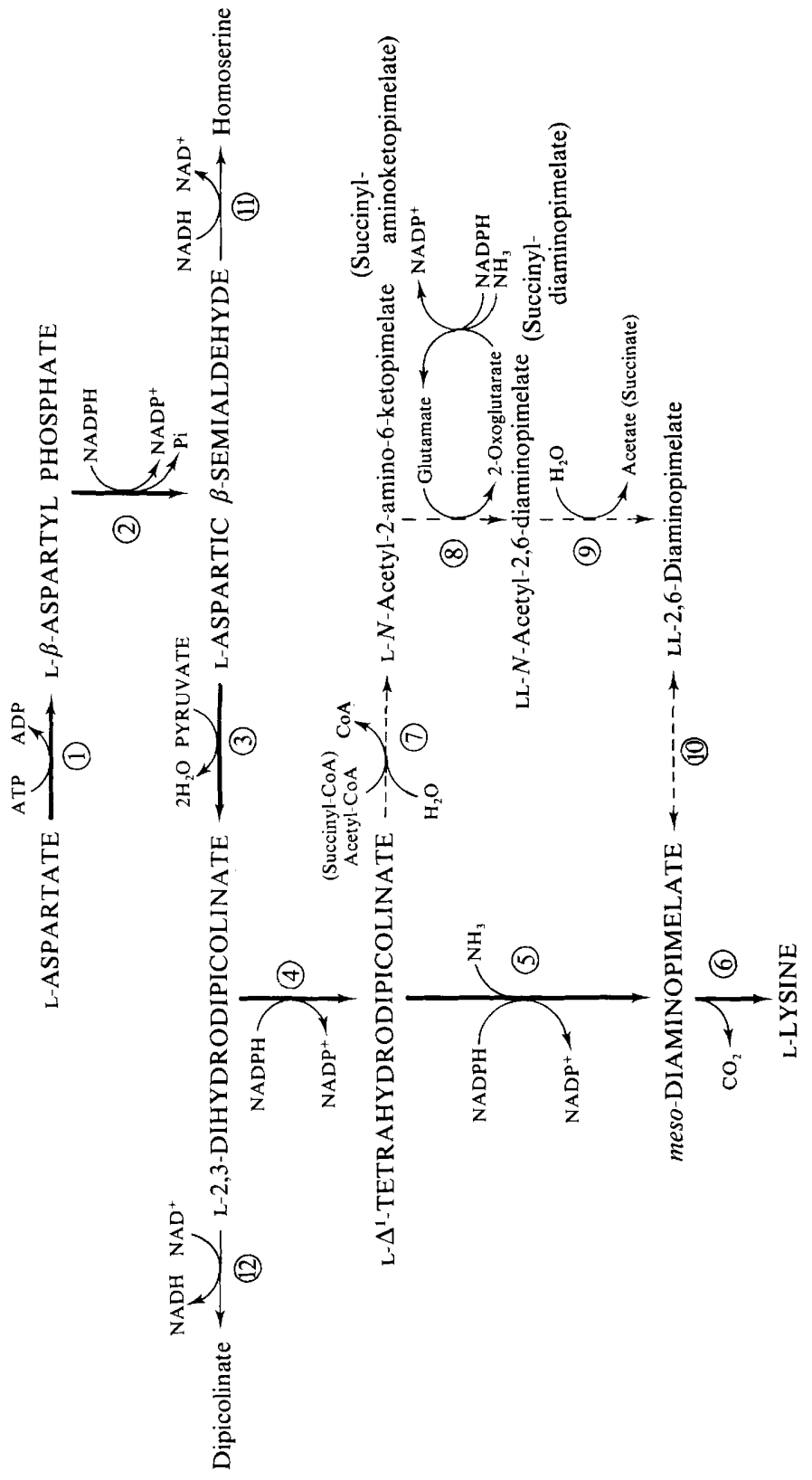

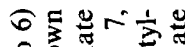

S 兽。灾

蚂高要之

要总造令

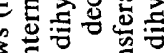

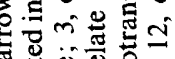

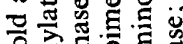

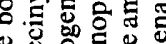

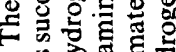

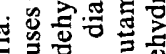

语

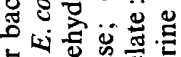

可苋苋

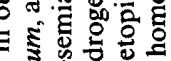

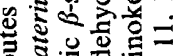

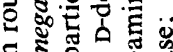

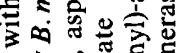

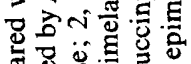

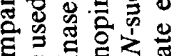

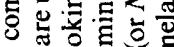

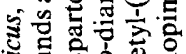

可焉焉

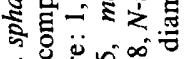



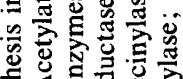

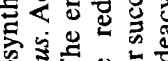

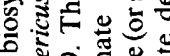

ษ 0 .

$\gtrsim n$

○.

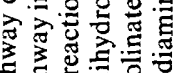

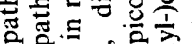

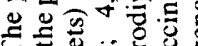

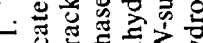

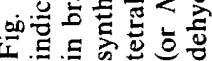


is entirely specific for meso-diaminopimelate. It therefore seemed possible that the proposed secondary route of lysine synthesis (Misono et al., 1979) was in fact the principal route in $\boldsymbol{B}$. sphaericus. Further evidence to support this view is given below.

\section{METHODS}

Organisms. Bacillus sphaericus NCTC 9602 was maintained on slopes of nutrient agar, which were incubated at $30^{\circ} \mathrm{C}$ and kept at $2{ }^{\circ} \mathrm{C}$. Bacillus megaterium NCIB 7581 and E. coli W (ATCC 9637) were maintained similarly, but the slopes were incubated at $37^{\circ} \mathrm{C}$.

Media. The defined medium A3 was used for most experiments with $B$. sphaericus. This medium contains sodium acetate $3 \mathrm{H}_{2} \mathrm{O}\left(5 \mathrm{~g}^{-1}\right)$ and trisodium citrate $2 \mathrm{H}_{2} \mathrm{O}\left(20 \mathrm{mg} \mathrm{1}^{-1}\right)$ as the only sources of carbon, and it was prepared as described by White \& Lotay (1980). In a few experiments with $B$. sphaericus nutrient broth was used. Bacillus megaterium and E. coli were grown in medium Al (White, 1972) with biotin and trisodium citrate added for B. megaterium (White, 1979).

Growth of cultures. Batch cultures of $B$. sphaericus were grown at $30^{\circ} \mathrm{C}$ in liquid medium, and growth was assessed turbidimetrically as described by White \& Lotay (1980). Cultures of E. coli and B. megaterium were grown similarly, but at $37^{\circ} \mathrm{C}$.

Enzyme assays. Bacterial extracts were made by passage of suspensions through a pressure cell (Milner $e t$ al., $1950)$ at $140 \mathrm{MPa}$ and assayed for protein (by the Lowry method) as described by Chatterjee \& White (1982). Procedures for assay of individual enzymes were as listed by Chatterjee \& White (1982), with the following additional methods: dihydrodipicolinate synthase (EC 4.2.1.52) was sometimes assayed by the method of Yamakura et al. (1974); dihydrodipicolinate reductase (EC 1.3.1.26) was measured as described by Kimura (1975), with dihydrodipicolinate (about $2 \mu \mathrm{mol} \mathrm{L}$-isomer per assay mixture) that had been made by non-enzymic reaction between pyruvate and aspartic $\beta$-semialdehyde in $1 \mathrm{M}-\mathrm{KOH}$ (see below); meso-diaminopimelate $\mathrm{D}$ dehydrogenase was assayed in the direction of synthesis of diaminopimelate, with L-2-amino-6-ketopimelate, $\mathrm{NH}_{4}{ }^{+}$and NADPH as substrates, at $\mathrm{pH} 7.5$ (Misono \& Soda, 1980); $N$-succinyl-LL-diaminopimelate desuccinylase (EC 3.5.1.18) was assayed as described by Kindler (1962), but on half-scale. Some variations of these general procedures for preparation of extracts and for enzymic assays are given in Results.

Synthesis of diaminopimelate from aspartic $\beta$-semialdehyde plus pyruvate. Formation of diaminopimelate by extracts of $B$. sphaericus took place in a system derived from that used to measure its synthesis with $E$. coli (Gilvarg, 1962). The following were mixed in a small test tube $(100 \times 10 \mathrm{~mm})$ to a total volume of $0.9 \mathrm{ml}$ (before adding extract): Tris/ $\mathrm{HCl}$ buffer pH $7.5(200 \mu \mathrm{mol})$; NADPH $(0.1 \mu \mathrm{mol})$; glucose-6-phosphate dehydrogenase $(10 \mu 1$; 1.4 units); glucose 6-phosphate disodium salt $(10 \mu \mathrm{mol}) ; \mathrm{NH}_{4} \mathrm{Cl}(200 \mu \mathrm{mol}) ;$ DL-aspartic $\beta$-semialdehyde $(2 \mu \mathrm{mol}$ L-isomer); sodium pyruvate $(10 \mu \mathrm{mol})$. The mixture was equilibrated at $30^{\circ} \mathrm{C}$ for $5 \mathrm{~min}$ while $\mathrm{N}_{2}$ was passed above the liquid surface (to minimize enzymic oxidation of NADPH with dissolved $\left.\mathrm{O}_{2}\right)$. Extract $(0.1 \mathrm{ml}$; about 1 to $2 \mathrm{mg}$ protein) was added, and a sample $(0.2 \mathrm{ml})$ was withdrawn at once from the mixture and put into $0.6 \mathrm{ml}$ ethanol. Again $\mathrm{N}_{2}$ was passed over the enzymic reaction mixture at $30^{\circ} \mathrm{C}$ for $2 \mathrm{~min}$ and the tube was then capped and incubated for $1 \mathrm{~h}$ (from the time of adding the extract). A further sample of the mixture $(0.2 \mathrm{ml}$ ) was finally added to ethanol $(0.6 \mathrm{ml})$. Material precipitated by the ethanol was removed by centrifugation. Part of the supernatant liquid $(0.4 \mathrm{ml})$ was evaporated to dryness at $40^{\circ} \mathrm{C}$ under diminished pressure, then taken up in water $(0.1 \mathrm{ml})$. Acetic acid $(0.8 \mathrm{ml})$ and ninhydrin reagent $(0.1 \mathrm{ml})$ were added, and this mixture was incubated at $37{ }^{\circ} \mathrm{C}$ for $90 \mathrm{~min}$ before reading the absorbance at $440 \mathrm{~nm}$ as a measure of diaminopimelate (Work, 1957); the ninhydrin reagent was $50 \mathrm{mg}$ ninhydrin in $0.8 \mathrm{ml} 0.6 \mathrm{M}$-orthophosphoric acid plus $1.2 \mathrm{ml}$ glacial acetic acid. Another portion of the supernatant liquid $(0.1 \mathrm{ml})$ from the ethanol precipitation was spotted on to paper to test chromatographically for the presence of diaminopimelate (see below). Control mixtures were incubated without extract, and without individual substrates (see Results).

To measure synthesis of diaminopimelate from dihydrodipicolinate the procedure was similar, except that aspartic $\beta$-semialdehyde and pyruvate were omitted from the enzymic reaction mixture, and instead dihydrodipicolinate (prepared non-enzymically; about $2 \mu \mathrm{mol} \mathrm{L}$-isomer) was added.

Chromatography. Descending chromatograms on Whatman no. 1 paper were developed with the solvent methanol/pyridine/ $11.6 \mathrm{M}-\mathrm{HCl} /$ water $(80: 10: 2 \cdot 5: 17 \cdot 5$, by vol; Rhuland et al., 1955). After drying the paper, spots were revealed with ninhydrin. Use of the above solvent, followed by ninhydrin, leads to a diaminopimelate spot with a very characteristic dull green colour, which changes in about $\mathrm{l} h$ to bright yellow. The solvent also separates the LL-isomer of diaminopimelate from the meso-isomer and DD-isomer; lysine migrates further than any isomer of diaminopimelate and gives a brown spot.

Isolation of lysine-requiring mutants of B. sphaericus. A series of $250 \mathrm{ml}$ conical flasks containing medium A3 ( $25 \mathrm{ml}$ per flask) was inoculated with B. sphaericus (wild-type). The size of the inoculum ranged from $2 \mathrm{ml}$ to $0 \cdot 1 \mathrm{ml}$ of an aqueous suspension of organisms $\left(10^{8} \mathrm{ml}^{-1}\right)$ from a nutrient agar slope. The flasks were incubated overnight at $30^{\circ} \mathrm{C}$ on a mechanical shaker. The following day a flask was chosen in which the bacteria were in the early exponential phase of growth (EEL colorimeter reading about 0.5 ; roughly $5 \times 10^{8}$ organisms ml-1), and $5 \mathrm{ml}$ of the 
culture was put into a test tube. To this was added $N$-methyl $-N^{\prime}$-nitro- $N$-nitrosoguanidine $(0.5 \mathrm{mg}$, as a freshly prepared aqueous solution) and the suspension was rocked at $30^{\circ} \mathrm{C}$ for $10 \mathrm{~min}$. A portion of this $(0.2 \mathrm{ml})$ was then added to $50 \mathrm{ml}$ nutrient broth which was incubated overnight with shaking, to allow phenotypic expression. The following day the organisms were starved by adding $0.05 \mathrm{ml}$ of the broth culture to $5 \mathrm{ml}$ medium $\mathrm{A} 3$, and rocked at $30^{\circ} \mathrm{C}$ for $4 \mathrm{~h}$. Benzyl penicillin $(5 \mu \mathrm{g}$, as an aqueous solution) was added, and the incubation was continued for $1 \mathrm{~h}$. The bacteria were centrifuged and resuspended in $50 \mathrm{ml}$ medium A3 plus L-lysine $\left(100 \mu \mathrm{g} \mathrm{ml}^{-1}\right)$ which was incubated overnight with shaking to allow outgrowth of lysine-requiring mutants. The next day the organisms from this culture were starved in medium A3 and treated with benzyl penicillin as before. Instead of centrifuging, the culture was diluted, plated on to nutrient agar and incubated overnight. Generally, $0.1 \mathrm{ml}$ of a 100 -fold dilution gave about 100 colonies. Prospective lysine-requiring auxotrophs were recognized by replica-plating on to medium $\mathrm{A} 3$ and $\mathrm{A} 3$ plus lysine. The mutants were further screened by tests on solid and liquid media. Some variations of the selection procedure are described in Results.

Chemicals. DL-Aspartic $\beta$-semialdehyde was made by ozonolysis of DL-allyl glycine (Black \& Wright, 1955a). After ion-exchange chromatography of the reaction mixture, the fractions which contained aspartic $\beta$ semialdehyde were identified by the formation of a purple adduct with 2-aminobenzaldehyde when the fractions were incubated with pyruvate and a crude extract of $E$. coli. The following were mixed in a small test tube: sodium phosphate buffer $\mathrm{pH} 7.4(100 \mu \mathrm{mol})$; sodium pyruvate $(10 \mu \mathrm{mol}) ; 2$-aminobenzaldehyde $(0.5 \mathrm{mg}) ;$ column fraction $\left(0.1 \mathrm{ml}\right.$, neutralized with $\left.\mathrm{NaHCO}_{3}\right)$; extract (about $1 \mathrm{mg}$ protein); water to $1 \mathrm{ml}$. The mixture was incubated at $30^{\circ} \mathrm{C}$ for $30 \mathrm{~min}$ before the absorbance at $540 \mathrm{~nm}$ was measured. Fractions that contained aspartic $\beta$-semialdehyde were pooled and the concentration of this compound ( $\mathrm{L}$-isomer) was found by the aspartic $\beta$-semialdehydedependent oxidation of NADH which is catalysed by homoserine dehydrogenase (Black \& Wright, 1955b). A crude extract of $E$. coli was satisfactory as a source of this enzyme, provided that the reaction was done in an anaerobic cuvette $\left(\mathrm{N}_{2}\right.$ atmosphere), so that there was no oxidation of NADH by the extract until the substrate was added. Aspartic $\beta$-semialdehyde was kept at $-60^{\circ} \mathrm{C}$ as a solution in $4 \mathrm{M}-\mathrm{HCl}$.

2-Aminobenzaldehyde was obtained from Fluka. Some batches of this material were polymerized; only material that will dissolve in $20 \%(\mathrm{v} / \mathrm{v})$ aqueous ethanol to give a solution containing $5 \mathrm{mg} \mathrm{ml}^{-1}$ is suitable for the assays described here.

To prepare dihydrodipicolinate, a solution ( $2 \mathrm{ml}$ ) of DL-aspartic $\beta$-semialdehyde in $4 \mathrm{M}-\mathrm{HCl}$ (containing $64 \mu \mathrm{mol}$ L-aspartic $\beta$-semialdehyde) at $20^{\circ} \mathrm{C}$ was added slowly, with mixing, to a solution $(1.1 \mathrm{ml})$ of sodium pyruvate $(135 \mu \mathrm{mol})$ in $11 \mathrm{M}-\mathrm{KOH}$ (Kimura, 1974). The mixture, which became yellow after about an hour, was left to stand overnight. The $\mathrm{pH}$ was lowered by cautious addition of $6 \mathrm{M}-\mathrm{HCl}$, and excess acid removed by adding solid $\mathrm{NaHCO}_{3}$ until effervescence stopped. This solution was used at once in assays for dihydrodipicolinate reductase and in measurements of synthesis of diaminopimelate by extracts; its concentration was assumed to be about $10 \mu \mathrm{mol} \mathrm{L}$-dihydrodipicolinate $\mathrm{ml}^{-1}$. A new preparation was made freshly each day it was needed, usually on onequarter of the scale described above.

L- $\Delta^{\prime}$-Tetrahydrodipicolinate (L-2-amino-6-ketopimelate) was made enzymically from meso-diaminopimelate by the action of diaminopimelate dehydrogenase, in a modification of the procedure of Misono et al. (1979) which was adopted to economize on use of NADP. The following were mixed in a $500 \mathrm{ml}$ conical flask: $\mathrm{NaHCO}_{3} / \mathrm{Na}_{2} \mathrm{CO}_{3}$ buffer, $\mathrm{pH} 10.5(8 \mathrm{mmol})$; NADP $(16 \mathrm{mg})$; phenazine ethosulphate $(8 \mathrm{mg})$; dichlorophenolindophenol (oxidized; $50 \mathrm{mg}$ ); diaminopimelic acid [ $4 \mathrm{mmol}$; synthetic; $50 \%$ (w/w) meso-isomer]; water to $200 \mathrm{ml}$ (final volume after adding enzyme). The solution was stirred at $37^{\circ} \mathrm{C}$ and diaminopimelate dehydrogenase (10 units; $10 \mathrm{mg}$ protein) was added. When the blue colour of the reaction mixture disappeared, more dichlorophenolindophenol $(50 \mathrm{mg})$ was added as an aqueous solution $\left(10 \mathrm{mg} \mathrm{ml}^{-1}\right)$. Additions were made at intervals over about $2 \mathrm{~h}$ until the reaction mixture was permanently blue and smelled of ammonia. The $\mathrm{pH}$ was brought to 1 by adding $6 \mathrm{M}-\mathrm{HCl}$, and the precipitated material was removed by centrifuging. The supernatant liquid was applied to a column of Dowex 50, which was eluted as described by Misono et al. (1979). Fractions (10 $\mathrm{ml})$ were tested $(0.13 \mathrm{ml}$ per assay) for ninhydrin-positive material by the method of Gilvarg (1958) with a heating time of $20 \mathrm{~min}$. Fractions which were positive were then tested with 2-aminobenzaldehyde: each fraction $(0.4 \mathrm{ml}$, neutralized with $\mathrm{NaHCO}_{3}$ ) was mixed with $1 \mathrm{M}$-imidazole buffer, $\mathrm{pH} 7.4(0.1 \mathrm{ml})$ and $0.5 \mathrm{ml}$ 2-aminobenzaldehyde [ $1 \mathrm{mg} \mathrm{ml}^{-1}$ in $20 \%(\mathrm{v} / \mathrm{v})$ aqueous ethanol] then incubated at $30^{\circ} \mathrm{C}$ for $1 \mathrm{~h}$ before measuring the absorbance at 440 $\mathrm{nm}$. Fractions 10 to 20 (eluted by $1 \mathrm{M}-\mathrm{HCl}$ ) were positive with 2-aminobenzaldehyde and the absorption spectrum (in the visible range) of the adduct was almost identical to that of the adduct formed by authentic $\Delta^{1}$ tetrahydrodipicolinate (Farkas \& Gilvarg, 1965). No other fractions gave a visible colour with 2aminobenzaldehyde. Fractions 10 to 20 were also the only fractions which gave a colour with 2,4dinitrophenylhydrazine: each fraction $(0.5 \mathrm{ml})$ was mixed at $37^{\circ} \mathrm{C}$ with $0.1 \mathrm{ml}$ of a solution of 2,4dinitrophenylhydrazine $\left(1 \mathrm{mg} \mathrm{ml}^{-1}\right)$ in $2 \mathrm{M}-\mathrm{HCl}$, and $0.4 \mathrm{ml}$ water. The absorbance at $415 \mathrm{~nm}$ was measured after $10 \mathrm{~min}$. The pooled fractions 10 to 20 were dried by evaporation under diminished pressure. The yield of crude 2amino-6-ketopimelate was only $20 \mathrm{mg}$. The material was taken up in water (to give a concentration of $10 \mu \mathrm{mol}$ $\mathrm{ml}^{-1}$ ), and kept at $-15^{\circ} \mathrm{C}$. 
Diaminopimelate dehydrogenase was partly purified from $B$. sphaericus (grown in nutrient broth) as described by Chatterjee \& White (1982). Glucose-6-phosphate dehydrogenase (from yeast) was from Boehringer.

Isomers of diaminopimelate were prepared as described by Saleh \& White (1976). N-Succinyl-LLdiaminopimelic acid was prepared from LL-diaminopimelate $(200 \mathrm{mg})$ as described by Gilvarg (1959).

\section{RESULTS}

\section{Assays for diaminopimelate epimerase and decarboxylase}

Bacillus sphaericus NCTC 9602 was grown in medium A3 and the washed bacteria were broken (see Methods). The supernatant liquid (extract) obtained after centrifugation of the debris at $20000 \mathrm{~g}$ for $20 \mathrm{~min}$ contained diaminopimelate decarboxylase $\left[50 \mathrm{nmol} \mathrm{CO} \mathrm{min}^{-1}(\mathrm{mg}\right.$ protein $)^{-1}$ ] which was measured manometrically (White, 1971). In the same extract no diaminopimelate epimerase could be detected manometrically (White et al., 1969). There was still no activity when broken organisms were assayed without preliminary centrifugation.

Neither broken organisms nor an extract could form meso-diaminopimelate (or lysine) from LL-diaminopimelate (shown by chromatography) in the system of Antia et al. (1957), even after incubation for $18 \mathrm{~h}$ at $30^{\circ} \mathrm{C}$. These experiments were done at $\mathrm{pH} 5$ (sodium acetate buffer), $\mathrm{pH} 6, \mathrm{pH} 7$ (phosphate buffer), $\mathrm{pH} 8$ (phosphate buffer or Tris/ $\mathrm{HCl}$ buffer) and $\mathrm{pH} 9$ (borate buffer), with and without an activator (1 mm-2,3-dimercaptopropan-1-ol). Bacteria dried with acetone (Antia et al., 1957) were also inactive in these tests. Finally, a lysozyme digest (of organisms harvested in the early part of the exponential phase of growth) was tested by manometric and chromatographic methods, but no diaminopimelate epimerase was found. In all these experiments, an extract of $B$. megaterium served as a control to show that diaminopimelate epimerase could be detected by the assay systems.

Extracts were tested in the spectrophotometric assay system for diaminopimelate dehydrogenase, with LL-diaminopimelate as substrate, at various $\mathrm{pH}$ values between 6.5 to 10.5 , at all of which diaminopimelate dehydrogenase showed easily measurable activity with mesodiaminopimelate. In no case was an increase of absorbance seen at $340 \mathrm{~nm}$, which implies that the LL-isomer could not be epimerized. Addition of meso-diaminopimelate or an extract of $B$. megaterium to the test systems led to a rapid rise of absorbance at $340 \mathrm{~nm}$.

\section{Other enzymes of the pathway to diaminopimelate}

All the enzymes needed to form tetrahydrodipicolinate from aspartate plus pyruvate were present in an extract of $B$. sphaericus (Table 1). There was, however, no reaction between 2amino-6-ketopimelate (tetrahydrodipicolinate) and acetyl-CoA or succinyl-CoA, and no deacylation of $N$-acetyl- or $N$-succinyl-LL-diaminopimelate in the presence of the extract. On the other hand, diaminopimelate dehydrogenase had very high activity in the extract, whether measured in the direction of synthesis of meso-diaminopimelate (at $\mathrm{pH} 7 \cdot 5$ ) or in the direction of oxidation of this compound (at $\mathrm{pH} \mathrm{10 \cdot 5).}$

\section{Synthesis of diaminopimelate from aspartic $\beta$-semialdehyde}

Incubation of an extract of $B$. sphaericus 9602 with aspartic $\beta$-semialdehyde plus pyruvate (under conditions described in Methods) led to the formation of diaminopimelate, which was assayed colorimetrically, and identified as the meso-isomer by chromatography. After $1 \mathrm{~h}$ at $30^{\circ} \mathrm{C}$ about $0.2 \mu \mathrm{mol}$ had been formed by $1 \mathrm{mg}$ protein. No synthesis occurred when the above two substrates or NADPH were omitted. Formation of diaminopimelate from dihydrodipicolinate (in place of aspartic $\beta$-semialdehyde plus pyruvate) was shown by chromatography; omission of $\mathrm{NH}_{4} \mathrm{Cl}$ diminished (by about half) the size and intensity of the spot on the final chromatogram due to meso-diaminopimelate. In no experiment was any synthesis of lysine detected by chromatography. This could have resulted from the absence of pyridoxal phosphate and the slightly alkaline incubation conditions, both of which would have limited the activity of diaminopimelate decarboxylase. 
Table 1. Activities of enzymes of lysine biosynthesis in B. sphaericus NCTC 9602

\begin{abstract}
Organisms were grown in medium A3 in the absence or presence of $L$-lysine $\left(100 \mathrm{mg} \mathrm{l}^{-1}\right)$ and extracts were made and assayed for enzymes as described in Methods. All the assays were done at $30^{\circ} \mathrm{C}$ and no attempt was made to alter the published procedures (in order to record maximal activities for $B$. sphaericus). Activities are in $\mathrm{nmol} \mathrm{min}^{-1}$ (mg protein) ${ }^{-1}$ except for dihydrodipicolinate synthase, which was assayed by the method of Shedlarsky (1971) and the activity is given as units of enzyme (mg

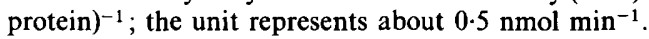

Enzyme

Aspartokinase

Aspartic $\beta$-semialdehyde dehydrogenase

(Homoserine dehydrogenase)

Dihydrodipicolinate synthase

Dihydrodipicolinate reductase

Diaminopimelate dehydrogenase $\mathrm{pH} 7.5^{*}$

Diaminopimelate dehydrogenase $\mathrm{pH} 10.5 \dagger$

Diaminopimelate decarboxylase

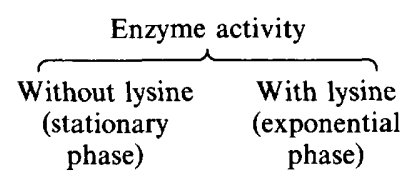

$\begin{array}{rr}14 & 14 \\ 38 & 25 \\ 18 & 25 \\ 20 & 41 \\ 29 & 62 \\ 474 & \text { ND } \\ 574 & 711 \\ 77 & 57\end{array}$

ND, Not determined.

* 2-Amino-6-ketopimelate plus $\mathrm{NH}_{4} \mathrm{Cl}$ as substrates.

$\dagger$ meso-Diaminopimelate as substrate.

\title{
Lysine-requiring mutants of $B$. sphaericus
}

Because diaminopimelate itself is not needed as a structural component of vegetative peptidoglycan in $B$. sphaericus, auxotrophs can be isolated that are blocked at various steps in the synthesis of diaminopimelate yet which grow in minimal medium supplemented only with lysine. The selection of a mutant that requires lysine and still has all the enzymes of the pathway, except for diaminopimelate dehydrogenase, would indicate that this latter enzyme does have an essential role in the biosynthesis of lysine.

Lysine-requiring auxotrophs of $\boldsymbol{B}$. sphaericus were isolated (see Methods) and extracts were assayed for various enzymes (Table 2). Since none of the mutants required homoserine (or methionine plus threonine), it was unlikely that aspartokinase or aspartic $\beta$-semialdehyde dehydrogenase would be absent, and indeed these enzymes were present in every mutant that was tested.

One mutant (M1) had no diaminopimelate dehydrogenase, whether assayed in the direction of reduction of $\mathrm{NADP}^{+}($at $\mathrm{pH} \mathrm{10 \cdot 5)}$ with meso-diaminopimelate as substrate, or in the opposite direction (at pH 7.5) with 2-amino-6-ketopimelate as substrate. All of the other enzymes needed to make tetrahydrodipicolinate were present, as was diaminopimelate decarboxylase. An extract of mutant M1 was unable to form diaminopimelate from dihydrodipicolinic acid. When liquid minimal medium A3 was inoculated with mutant $\mathrm{M} 1$, turbidity appeared after $3 \mathrm{~d}$ at $30^{\circ} \mathrm{C}$. On transfer to fresh minimal medium these revertants grew as quickly as the wild-type, and an extract of revertant organisms had considerable activity [125 nmol NADPH formed $\min ^{-1}(\mathrm{mg} \text { protein })^{-1}$ ] of diaminopimelate dehydrogenase.

All of the other mutants were deficient at one of the other enzymic steps between aspartic $\beta$ semialdehyde and lysine (Table 2). Using substrate that had been made chemically proved very advantageous in the assay for dihydrodipicolinate reductase. After the incubation of aspartic $\beta$ semialdehyde overnight in $1 \mathrm{M}-\mathrm{KOH}$ (with pyruvate) very little of this compound remains (Kimura, 1975). In contrast, when dihydrodipicolinate is generated enzymically, the residual aspartic $\beta$-semialdehyde may be a substrate for homoserine dehydrogenase, so that assays for dihydrodipicolinate reductase give erroneously high results with a crude extract. Inactivation of homoserine dehydrogenase by heating briefly to $70^{\circ} \mathrm{C}$ (Tamir, 1971) was unsatisfactory with extracts of $B$. sphaericus, almost all the protein was coagulated, and no activity of 


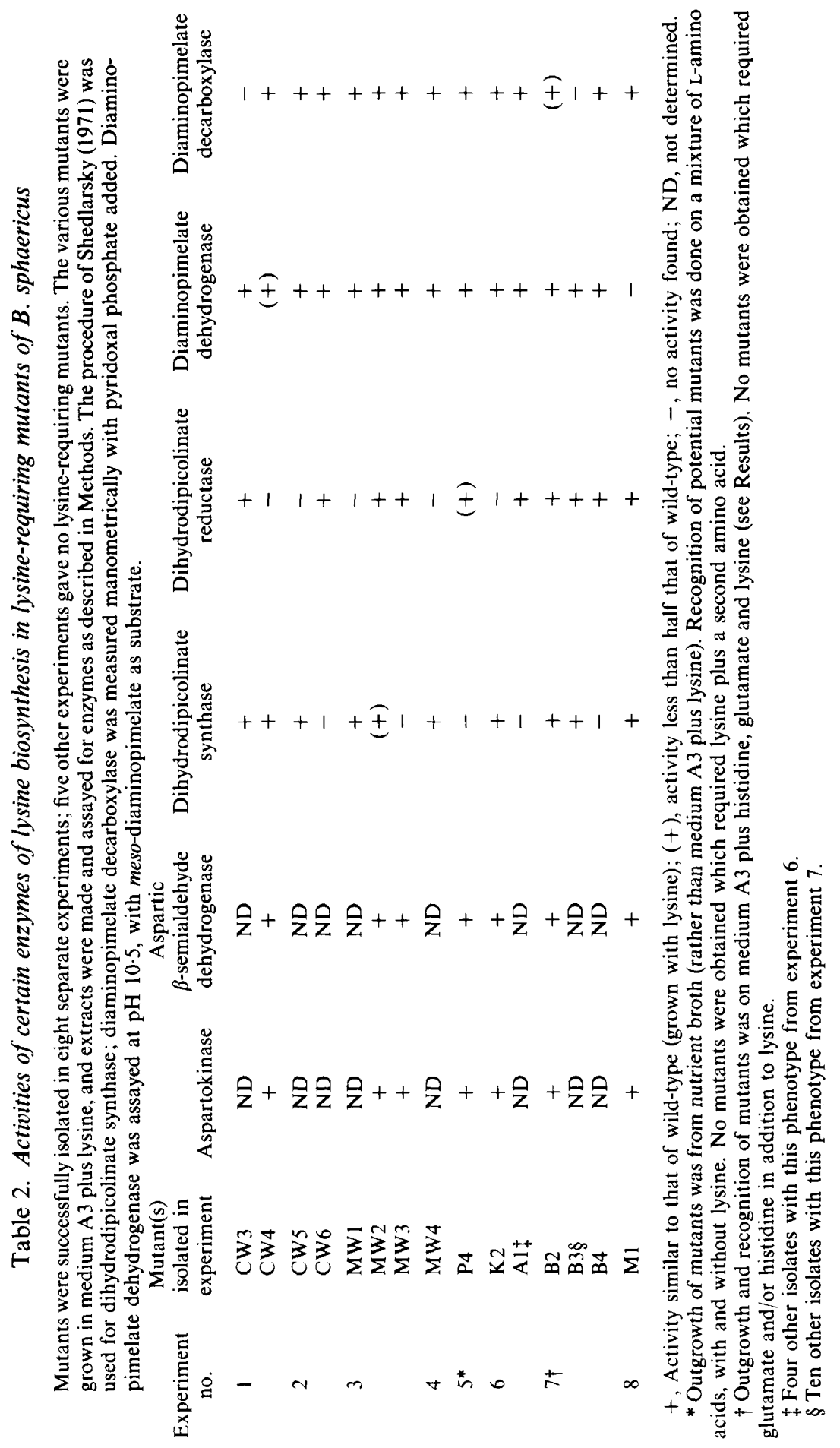


dihydrodipicolinate reductase was left in the supernatant liquid. Two mutants, MW2 and B2, seemed at first to lack none of the enzymes of the lysine pathway. In the assay of Shedlarsky (1971) mutant MW2 had slight activity of dihydrodipicolinate synthase, but the extract was inactive in the more precise assay system of Yakamura et al. (1974). The extract made diaminopimelate from dihydrodipicolinate, but there was no synthesis from aspartic $\beta$ semialdehyde (plus pyruvate). Mutant B2 could form diaminopimelate from aspartic $\beta$ semialdehyde just as well as the wild-type, and seemed to have all the enzymes necessary to make lysine. However, in this mutant, diaminopimelate decarboxylase proved to be abnormal. When measured with pyridoxal phosphate in the assay system the activity was $27 \mathrm{nmol} \mathrm{min}{ }^{-1}(\mathrm{mg}$ protein $)^{-1}$; with pyridoxal or with no cofactor the activity was zero. After growth in medium A3 plus lysine the wild-type activities were $\left[\mathrm{nmol} \mathrm{m^{-1 }}\left(\mathrm{mg}\right.\right.$ protein) $\left.{ }^{-1}\right]$ : 57 with pyridoxal phosphate; 44 with pyridoxal; and 31 with no cofactor (cf. Meadow \& Work, 1958a).

Several of the mutants that were blocked before diaminopimelate (CW4, CW5, CW6, MW1, MW2, MW3 and MW4) were tested for growth in liquid medium A3 plus diaminopimelate (meso-isomer, or LL-isomer or synthetic) at various concentrations up to $1 \mathrm{mg} \mathrm{ml}{ }^{-1}$. None showed appreciable growth within $4 \mathrm{~d}$. 2-Amino-6-ketopimelate (1 mM) failed to support growth of mutants M1, P4, K2, A1, B2, B3, B4 on solid medium A3.

\section{Nitrogen requirements of $B$. sphaericus}

When each lysine-requiring mutant was obtained it was first screened for activity of diaminopimelate dehydrogenase at $\mathrm{pH} 10.5$ with meso-diaminopimelate as substrate. Some 20 auxotrophs were isolated before one was found which lacked this enzyme. It seemed possible that the enzyme might be needed for assimilation of ammonia (see later) so that a mutant lacking the dehydrogenase might require some organic source of nitrogen, and might fail to grow in medium A3 plus lysine.

Neither L-lysine nor L-glutamate allowed growth of the wild-type in medium A3 from which ammonium ions were omitted (White \& Lotay, 1980). Nitrate and urea were also ineffective, but a mixture of six L-amino acids (aspartate, glutamate, proline, phenylalanine, arginine and histidine; each at $200 \mathrm{mg} \mathrm{1}^{-1}$ ) did support growth. Progressive omissions showed that Lglutamate plus L-histidine ( 400 and $200 \mathrm{mg} \mathrm{l}^{-1}$, respectively) could replace ammonium ions, and some mutants were then isolated from medium A3 supplemented with these two amino acids and lysine (Table 2).

Subsequently, L-glutamine (or L-asparagine) proved to be adequate as a single source of nitrogen for $B$. sphaericus 9602 . The lowest concentration of L-glutamine that did not restrict growth was $1 \mathrm{~g} \mathrm{l}^{-1}$, which represents $190 \mathrm{mg}$ nitrogen $1^{-1}$. At least $11 \mathrm{~mm}-\mathrm{NH}_{4} \mathrm{Cl}(154 \mathrm{mg}$ nitrogen $1^{-1}$ ) was needed to support maximal growth when this salt was sole source of nitrogen. If nitrogen makes up $15 \%$ of the bacterial dry weight, then growth to the observed maximal density $\left(1 \mathrm{~g}\right.$ dry wt $\left.\mathrm{1}^{-1}\right)$ should require a supply of $150 \mathrm{mg}$ nitrogen $\mathrm{l}^{-1}$.

In contrast, the lowest concentration of L-lysine that supported full growth of all the mutants tested was $50 \mathrm{mg} \mathrm{l}^{-1}$, which represents only $10 \mathrm{mg}$ nitrogen $\mathrm{l}^{-1}$. If protein makes up $50 \%$ of the bacterial dry weight and peptidoglycan represents a further $10 \%$, then $1 \mathrm{~g}$ dry wt of organisms will contain about $50 \mathrm{mg}$ of lysine residues. It seems very probable, therefore, that lysine in the medium is a source of this amino acid for biosynthesis, but that lysine is not a general source of nitrogen.

\section{Non-invoivement of diaminopimelate dehydrogenase in the assimilation of ammonia by $B$. sphaericus}

White \& Lotay (1980) found that glutamate dehydrogenase was present in B. sphaericus 9602 , while glutamate synthase was absent. Diaminopimelate dehydrogenase catalysed the reductive amination of a carbon skeleton (2-amino-6-ketopimelate) in forming diaminopimelate, and transamination between diaminopimelate and some $\alpha$-keto acids has been claimed to occur in $B$. sphaericus (Meadow \& Work, 1958b). Hence, diaminopimelate dehydrogenase might play a part in the assimilation of ammonia by these bacteria.

The properties of the lysine-requiring mutants make this hypothesis unlikely. Mutant M1 
lacks diaminopimelate dehydrogenase but it grows in medium A3 supplemented only with lysine. All of the mutants blocked at dihydrodipicolinate synthase or dihydrodipicolinate reductase must be unable to form 2-amino-6-ketopimelate, yet all grow in medium A3 plus lysine, in some cases as quickly as the wild-type.

Attempts to detect transamination between synthetic diaminopimelic acid and 2oxoglutarate, catalysed by an extract of $B$. sphaericus 9602 in the system of Meadow \& Work $(1958 b)$, have been completely unsuccessful.

After dialysis, partially purified diaminopimelate dehydrogenase catalysed an anaerobic oxidation of NADPH at pH 7.5 that was dependent on the presence of both 2-amino-6ketopimelate and $\mathrm{NH}_{4} \mathrm{Cl}$. There was no reaction when L-glutamine (up to $5 \mathrm{mM}$ ) was used in place of $\mathrm{NH}_{4} \mathrm{Cl}$. The enzyme, therefore, does not seem able to function, at low concentrations of glutamine, as a counterpart of glutamate synthase (Meers et al., 1970).

\section{DISCUSSION}

Bacillus sphaericus NCTC 9602 grows with acetate as sole source of carbon (White \& Lotay, 1980 ), and so must make the lysine which occurs in its vegetative peptidoglycan (Hungerer \& Tipper, 1969) and in proteins. Aspartokinase, aspartic $\beta$-semialdehyde dehydrogenase, dihydrodipicolinate synthase, dihydrodipicolinate reductase and diaminopimelate decarboxylase are all readily detected in an extract of $B$. sphaericus. Furthermore, the extract can make meso-diaminopimelate from its precursors aspartic $\beta$-semialdehyde plus pyruvate, or from dihydrodipicolinate. However, the absence of diaminopimelate epimerase from $B$. sphaericus implies that neither of the established routes from tetrahydrodipicolinate to meso-diaminopimelate can operate in this organism. No enzyme was found in $B$. sphaericus that could catalyse a reaction between acetyl- or succinyl-CoA and tetrahydrodipicolinate, and crude extracts of these bacteria did not deacylate $N$-acetyl- or $N$-succinyl-LL-diaminopimelate. This latter observation makes it unlikely that epimerization of an acylated LL-diaminopimelate occurs (to form a derivative of meso-diaminopimelate), followed by the action of a novel deacylase, to yield meso-diaminopimelate.

The enzyme meso-diaminopimelate D-dehydrogenase reductively aminates tetrahydrodipicolinate at $\mathrm{pH} 7.5$ to produce meso-diaminopimelate in a single step, and the activity of this enzyme in $B$. sphaericus is much higher than any of the other enzymic activities in the lysine pathway. Bacillus sphaericus cannot readily take up diaminopimelate (mutants blocked in the synthesis of lysine before diaminopimelate are unable to grow with this amino acid in minimal medium) and so it is unlikely that diaminopimelate dehydrogenase is formed for the purpose of oxidizing diaminopimelate, even though such a reaction is readily catalysed by extracts (Antia \& Work, 1961). A function for this enzyme in the assimilation of ammonia is also doubtful (see Results). A role in the synthesis of meso-diaminopimelate appears much more probable.

Loss of diaminopimelate dehydrogenase by mutation caused a requirement for lysine, and the enzyme reappeared in a revertant that grew in minimal medium. All other lysine-requiring mutants (that have diaminopimelate dehydrogenase) are defective in one of the three enzymic steps in the suggested pathway (Fig. 1) between aspartic $\beta$-semialdehyde plus pyruvate, and lysine. A mutant lacking aspartokinase or aspartic semialdehyde dehydrogenase would fail to make homoserine, and so could not be selected by screening for the single requirement for lysine.

Lysine-requiring mutants of $B$. sphaericus have already been obtained by other workers (Imae \& Strominger, 1976; Linnett \& Tipper, 1976). These mutants were divided into three groups, those blocked at or before dihydrodipicolinate synthase, those blocked between dihydrodipicolinate and diaminopimelate, and those lacking diaminopimelate decarboxylase. This division was based on the properties of the spores formed by the mutants, and the individual enzymes were not examined.

Synthesis of meso-diaminopimelate by a single enzymic step from tetrahydrodipicolinate seems to offer advantages over the established pathways. No acetyl-or succinyl-CoA is needed, and four enzymes (Fig. 1, numbers 7 to 10) are not required. Perhaps the operation of four enzymes allows a more refined control of metabolic flow, but very little has been reported on the regulation of this part of the diaminopimelate pathway in any bacteria. 
In spite of its apparent advantages, the synthesis of meso-diaminopimelate via diaminopimelate dehydrogenase does not seem, on the basis of rather limited surveys, to be of wide occurrence. Misono et al. (1979) assayed 30 species of bacteria and found only four with appreciable activity of diaminopimelate dehydrogenase, while all the species examined (12) by Weinberger \& Gilvarg (1970) deacylated either $N$-succinyl- or $N$-acetyl-LL-diaminopimelate.

In certain eukaryotic organisms (euglenoids, higher fungi and some lower fungi) lysine is made by an entirely different route, in which 2-aminoadipic acid is a characteristic intermediate (see review by Meister, 1965). Vogel et al. (1970) have considered how this pathway and the diaminopimelate pathway might have evolved separately. If, as Vogel et al. (1970) proposed, the diaminopimelate pathway was evolved in ancient times by ancestral forms of modern bacteria and plants, then natural selection might have been expected to favour the most efficient of the three variants of this pathway, and to have eliminated the other two.

Miss Lorna B. Young has given excellent technical assistance throughout this work. Mr S. G. Calderbank established the conditions for selection of lysine auxotrophs, as part of an undergraduate research project. Miss Julie Massie isolated further mutants during her project. Assays for acetylation and succinylation of tetrahydrodipicolinate were done by Dr S. P. Chatterjee. Mrs Annie Bartlett made $N$-succinyl-LLdiaminopimelate and did the assays for deacylation of this compound. I am grateful to all these people for their help. The Department of Chemistry, University of Sheffield, kindly provided facilities for the ozonolysis of allylglycine.

\section{REFERENCES}

ANTIA, M. \& Work, E. (1961). Oxidation of meso- $\alpha, \varepsilon-$ diaminopimelic acid by certain sporulating species of bacteria. Journal of General Microbiology 26, 6780.

Antia, M., Hoare, D. S. \& Work, E. (1957). The stereoisomers of $\alpha \varepsilon$-diaminopimelic acid. 3. Properties and distribution of diaminopimelic acid racemase, an enzyme causing interconversion of the LL and meso isomers. Biochemical Journal 65, 448-459.

Black, S. \& Wright, N. G. (1955a). Aspartic $\beta$ semialdehyde dehydrogenase and aspartic $\beta$-semialdehyde. Journal of Biological Chemistry 213, 39-50.

BLACK, S. \& WRIGHT, N. G. (1955b). Homoserine dehydrogenase. Journal of Biological Chemistry 213, 51-ó0.

Chatterjee, S. P. \& White, P. J. (1982). Activities and regulation of the enzymes of lysine biosynthesis in a lysine-excreting strain of Bacillus megaterium. Journal of General Microbiology 128, 1073-1081.

FARKaS, W. \& Gilvarg, C. (1965). The reduction step in diaminopimelic acid synthesis. Journal of Biological Chemistry 240, 4717-4722.

Gilvarg, C. (1958). The enzymatic synthesis of diaminopimelic acid. Journal of Biological Chemistry 233, $1501-1504$.

GilvarG, C. (1959). N-succinyl-L-diaminopimelic acid. Journal of Biological Chemistry 234, 2955-2959.

GILVARG, C. (1962). Diaminopimelic acid synthesis in Escherichia coli. Methods in Enzymology 5, 848-850.

Hungerer, K. D. \& TipPeR, D. J. (1969). Cell wall polymers of Bacillus sphaericus 9602. 1. Structure of the vegetative cell wall peptidoglycan. Biochemistry 8, 3577-3587.

ImAe, Y. \& Strominger, J. L. (1976). Relationship between cortex content and properties of Bacillus sphaericus spores. Journal of Bacteriology 126, 907913.

Kimura, K. (1974). Pyridine-2,6-dicarboxylic acid (dipicolinic acid) formation in Bacillus subtilis. 1. Non-enzymatic formation of dipicolinic acid from pyruvate and aspartic semialdehyde. Journal of Biochemistry 75, 961-967.

KimURA, K. (1975). A new flavin enzyme catalysing the reduction of dihydrodipicolinate in sporulating Bacillus subtilis. 1. Purification and properties. Journal of Biochemistry 77, 405-413.

KINDLER, S. H. (1962). $\mathrm{N}$-Succinyl-L-diaminopimelic deacylase. Methods in Enzymology 5, 851-853.

LINNETT, P. E. \& TIPPER, D. J. (1976). Transcriptional control of peptidoglycan precursor synthesis during sporulation in Bacillus sphaericus. Journal of Bacteriology 125, 565-574.

MEadow, P. \& WORK, E. (1958a). The effects of vitamin $\mathbf{B}_{6}$ and its derivatives on diaminopimelic acid decarboxylase in Bacillus sphaericus asporogenous. Biochimica et biophysica acta 29, 180-187.

Meadow, P. \& WoRK, E. (1958b). Bacterial transamination of the stereoisomers of diaminopimelic acid and lysine. Biochimica et biophysica acta 28, 596599.

MeErs, J. L., Tempest, D. W. \& Brown, C. M. (1970). 'Glutamine (amide) :2-oxoglutarate amino transferase oxido-reductase (NADP)', an enzyme involved in the synthesis of glutamate by some bacteria. Journal of General Microbiology 64, 187-194.

MEISTER, A. (1965). Biochemistry of the Amino Acids, vol. 2, 2nd edn, pp. 928-951. New York: Academic Press.

Milner, H. W., Lawrence, N. S. \& French, C. S. (1950). Colloidal dispersion of chloroplast material. Science 111, 633-634.

Misono, H. \& SodA, K. (1980). Properties of meso- $\alpha, \varepsilon-$ diaminopimelate D-dehydrogenase from Bacillus sphaericus. Journal of Biological Chemistry 255, 10599-10605.

Misono, H., Togawa, H., Yamamoto, T. \& Soda, K. 
(1979). meso- $\alpha, \varepsilon$-Diaminopimelate D-dehydrogenase : distribution and the reaction product. Journal of Bacteriology 137, 22-27.

Powell, J. F. \& Strange, R. E. (1957). $\alpha \varepsilon^{-}$ Diaminopimelic acid metabolism and sporulation in Bacillus sphaericus. Biochemical Journal 65, 700-708.

Rhuland, L. E., Work, E., DenMan, R. F. \& Hoare, D. S. (1955). The behaviour of isomers of $\alpha, \varepsilon^{-}$ diaminopimelic acid on paper chromatograms. Journal of the American Chemical Society 77, 4844 4846.

Saleh, F. \& White, P. J. (1976). Use of auxotrophic mutants to isolate LL- or DD-isomers of 2,6-diaminopimelic acid. Journal of General Microbiology 96, 253-261.

SHEdlaRsky, J. G. (1971). Pyruvate-aspartic semialdehyde condensing enzyme (Escherichia coli). Methods in Enzymology 17B, 129-134.

Sundharadas, G. \& Gilvarg, C. (1967). Biosynthesis of $\alpha, \varepsilon$-diaminopimelic acid in Bacillus megaterium. Journal of Biological Chemistry 242, 3983-3984.

TAMIR, H. (1971). Dihydrodipicolinic acid reductase (Escherichia coli). Methods in Enzymology 17B, 134139.

Vogel, H. J., Thompson, J. S. \& Shockman, G. D. (1970). Characteristic metabolic patterns of prokaryotes and eukaryotes. Symposia of the Society for General Microbiology 20, 107-119.

Weinberger, S. \& Gilvarg, C. (1970). Bacterial distribution of the use of succinyl and acetyl blocking groups in diaminopimelic acid biosynthesis. Journal of Bacteriology 101, 323-324.
WhITE, P. J. (1971). Diaminopimelate decarboxylase (Escherichia coli). Methods in Enzymology 17B, 140145.

WhITE, P. J. (1972). The nutrition of Bacillus megaterium and Bacillus cereus. Journal of General Microbiology 71, 505-515.

WHITE, P. J. (1979). Effects of D-glutamate on enzymes of ammonia assimilation in Bacillus megaterium NCIB 7581. Journal of General Microbiology 114, $159-168$.

White, P. J. \& Lotay, H. K. (1980). Minimal nutritional requirements of Bacillus sphaericus NCTC 9602 and 26 other strains of this species: the majority grow and sporulate with acetate as sole major source of carbon. Journal of General Microbiology 118, 13-19.

White, P. J., Lejeune, B. \& Work, E. (1969). Assay and properties of diaminopimelate epimerase from Bacillus megaterium. Biochemical Journal 113, 589601.

WORK, E. (1957). Reaction of ninhydrin in acid solution with straight chain amino acids containing two amino groups and its application to the estimation of $\alpha, \varepsilon$-diaminopimelic acid. Biochemical Journal 67, 416-423.

Yamakura, F., IKeda, Y., Kimura, K. \& SaSaKawa, T. (1974). Partial purification and some properties of pyruvate-aspartic semialdehyde condensing enzyme from sporulating Bacillus subtilis. Journal of Biochemistry 76, 611-621. 